\title{
Boycott of South Africa
}

SiR-John Maddox's article "Science in Apartheid" (Nature 327, 269-276; 1987) is essential reading for anyone wanting to come to a conclusion about the correctness of the boycott tactic. However, the tone of your leader "Boycott someone and feel virtuous", and especially its sub-heading "The academic community should find a better way of making its good intentions come true" make me realize that a number of ambiguities remain in the Maddox article, ambiguities which led you to a conclusion opposite to that to which most of us would have come.

The major problem seems to lie in Maddox's statement that "one person, one vote, tomorrow would indeed be a recipe for disaster". The ambiguity here is: disaster for whom? Certainly for the privileged whites - but equally for the inhabitants of Soweto? Has, as Maddox writes, the non-white majority no political structure within which to organize its opinion? Why then is the African National Congress so courted by the great industrialists and now by the Progressive Party? The transition to a non-racial democratic society will surely be hard, but it must start today, not tomorrow, and with "one person, one vote". This ambiguity leads him to his second difficulty: what would be the conditions in which the boycotters would relent? If one is clear that "one person, one vote" is the blueprint for a South Africa acceptable to the black community, then the attainment of universal franchise is the point at which the boycott ceases.

We should be unambiguous about the aim of an academic boycott. Rather than to allow us to feel virtuous, its aim is to weaken the apartheid state so that its rulers become unable to hold power and proceed, rather, to negotiate with the African National Congress on the transfer of power. We should be clear, too, that this boycott is free of the liberal's major hesitation about economic sanctions. The latter obviously hurt blacks. Should they be asked to suffer if their voice in this matter is not given a hearing (as it cannot be tested by the ballot box)? As far as a science boycott is concerned, if South African science ceases for the five or ten years that might lie ahead before majority rule, hardly a black will suffer. Few are employed by the scientific establishment, little of the immediate results of this science will affect their standard of living. Those who will feel the effects, of course, are the scientists themselves, almost all of whom are white and privileged. But that is a function of the boycott, to make these scientists understand that their working in the South African scientific community is at least passive support for the apartheid system.
An issue that is still not clear to me is whether the boycott should be total. Perhaps the academic boycott needs its Sullivan Code. An international body could set up criteria for enabling journals to accept papers from South African authors who state their categorical rejection of apartheid, and who are from institutions that have publicly dissociated themselves from that system. Public discussion on these issues in South Africa will itself have important educational effects on the scientific community and beyond it. And the organizers of scientific meetings might consider what was discussed among the sportsmen and welcome, at international meetings, 'mixed' scientific delegations from South Africa. This stipulation would itself greatly encourage the acceptance of blacks into the graduate schools of the South African universities and their more rapid advancement to faculty positions. Scientists at institutions that refuse to accept the new code should be offered facilities abroad until they can return to a, hopefully, non-racial South Africa (Azania?) when this is set up.

It is important that the West seriously confronts the human problem of the postapartheid South Africa, which will involve the resettling of those people of all races who will feel unable to remain in South Africa under a new regime. Rather than making it difficult for South Africans to emigrate to the United States, Canada and the United Kingdon (and the Netherlands and France), they should already at this stage be encouraged to do so, and assisted in their resettlement.

Institute of Life Sciences,

W.D.STEIN

Hebrew University.

Jerusalem, Israel

SIR-Your feature on "Science in Apartheid" (Nature 327, 269-276; 1987) admirably challenged the smug ivory tower position that supposes science and scientists can be neutral and ignore the boycott issues.

No longer is the South African Council for Scientific and Industrial Research (CSIR) able to recruit 100 foreign scientists and technologists each year; no longer can South Africa sustain its science-intensive economy through overseas recruitment. Moreover, you make it clear that we now have a good chance through argumentation and ostracism of reversing the skill drain to South Africa and so hurting the CSIR and other government bodies.

Letters submitted for Correspondence should be typed, double-spaced, on one side of the paper only.
The CSIR differs of course from the British Science and Engineering Research Council (SERC). Not only does the CSIR cater for military as welll as civil research, but it is also engaged in economically important areas such as nuclear technology, oil-from-coal and mineral extraction/ processing.

One objection to the SERC link with the South African Astronomical Observatory (SAAO) was that CSIR personnel attended the UK Conferences on Southern Hemisphere Astronomy - people who were not astronomers but who could have been scouting for technological developments (satellite tracking, remote sensing, image-processing software) and for scientific specialists. Mysterious South African names similarly appear on the attendance lists of big international conferences such as that of the International Union for Geodesy and Geophysics.

The boycott clearly does harm science, in the short term. A programme to observe Halley's comet in which I was involved, having been turned down for the Anglo-Australian Telescope and diverted by SERC to the SAAO, instead made use of a significantly less suitable Californian telescope. On the other hand, apartheid is harming science and depriving potential scientists just because of skin colour.

Individual scientists lose out, unfortunately, but so do the South African blacks, who are deprived of higher education, let alone the chance of becoming scientists. We should now be confident that the scientific boycott can help to hasten the downfall of apartheid, and in the longer term benefit the cause of science as well as humanity.

University College, Cardiff,

Department of Applied

Mathematics and Astronomy,

Senghennydd Road, Cardiff CF2 $4 A G, U K$

\section{Brave new world}

SIR-The Commentary by Erwin Chargaff, "Engineering a molecular nightmare" (Nature 327, 199; 1987), not only shows Chargaff's wit and wisdom, but also his moral courage to stand up against the unacceptable. I disagree only with his assertion that "a gigantic slaughterhouse, a molecular Auschwitz, in which valuable enzymes, hormones and so on will be extracted instead of gold teeth" is to come. I rather think it has already arrived in the massive industrial exploitation of aborted fetuses, from which "beauty products" are made.

Universidad de Chile, Fernando OrRego

Facultad de Medicina,

Depto Fisiologia y Biofisica, Casilla 137-D Correo Central, Santiago, Chile 